ISSN 1112-9867

Available online at

http://www.jfas.info

\title{
APPROPRIATE STRATEGIES FOR DESIGNING CONTEMPORARY ART MUSEUMS WITH THE AIM OF ATTRACTING MORE PEOPLE IN SOCIOCULTURAL SPACES OF THE COUNTRY ( CASE STUDY: SARI, MAZANDARAN)
}

\author{
S. Z. Galogahi ${ }^{1, *}$, H. M. Beheshti ${ }^{2}$, M. Alishah ${ }^{2}$, S. R. Rasooli ${ }^{2}$ \\ ${ }^{1} \mathrm{MSc}$ in architecture engineering, instructor of Sama technical and vocational college, \\ Islamic Azad University, Sari Branch, Sari, Iran. \\ ${ }^{2}$ Graduate student, department of architecture, Sari University of Science and Research
}

Published online: 16 July 2016

\begin{abstract}
Museums that are brimful of precious cultural treasures and indicate the identity of a society reflect human thought and artistic creativity during different generations and can convey concepts to visitors through its public displays. Withthe assumptionthatthe museumscanenrich the culture of a country youngcommunity, this study has triedtotargetitsresearchtoinvestigateways toimprove the design ofthe contemporary art museumin Mazandaran. Therefore,using theSPSS softwaresample size was estimated 384 based on Morgan table, among which55.7\% were men and $44.3 \%$ were women. According tothesignificance level that wasless than 0.05 , the frequencydifferencebetween the two groups of responses turned out to be significantat $99 \%$. So the assumption that qualitative factors such as (aesthetic style designed for the set, easy access to the collections and availability of educational facilities) compared to individual and social factors such as (users' cultural and social conditions, visitors' economic situation, the sense of peace created by the presence of people in the building, etc.) have a greater impact on the category of visiting a museum is accepted.
\end{abstract}

Author Correspondence, e-mail: s_zakiann@yahoo.com

doi: http://dx.doi.org/10.4314/jfas.v8i2s.67 
Key words: museum, contemporary art, cultural interaction, public places.

\section{INTRODUCTION}

As a new phenomenon in the world of art, museums have taken different roles and functions. Exhibition, conservation, education and research can be regarded as museums different functions that have increasingly changed them intoculturalinstitutionsthat are affectingvarious aspects of today's societies (Mirzaie and Nadalian 2009, 93). Museumsshould not be considered asplaces where onlyancientmonumentsare shown, butallart and scientific fairs, galleries, libraries, archivesandmosthistoricalmonuments can be museums. Allobjects being displayed in museums have messages to send to their visitors and we canperceivethese messages by contemplationand study them from differentpoints of view (Kasiri, 2012, 70).One-off the most importantfunctions ofa museum is thecommunication it makes betweenvisitors andobjects displayed. In fact, we must striveto transfertheconnection and the feeling existed between thecreatorof a workandthe work itselftothevisitors, and thisis not beyond reach (DabiriNejad 2004, 96). Statistics indicate that in $19^{\text {th }}$ century only a specific group of people spent their time visiting museums (Dasam, 2008,70-120) and countries with various free admission museums have a small number of visitors, in fact for every 200 people going to movie theaters, only one person is visiting a museum. There is no room for doubt that establishing museums is important for showing human achievements. Additionally, in economicand profitability aspects, the world famousmuseumshave been successfulin attractingdomestic andforeign tourists (Nafisi, 2001, 30-43). Not only are museums an effective factor in cultural and educational fields, but also they affect countries process of gaining international identity. Todays, almost all tourists know museums such as the Louvre Museum in Paris, the British Museum in London, and the Hermitage Museum in Saint Petersburg. These museums are a part of the identity and civilization of the country holding them (Lotfi, 2007, 74-82). It is important for countries like Iran with young, educated and talented population to increase the number of their museums. This way the art status can affect the injection of new ideas through its evolution. Additionally, it should be noted that in today's world the museums have a comprehensive mission to conduct that is interpretation of covert concepts existing in artistic works and transferring their values to all groups of people especially ordinary people. This way people can enjoy their free time with their families as they are learning about educational and cultural values of the works. Actually, museums are presented to all people in a society disregarding their age, gender or cultural and social groups and it can be claimed that museums are appropriate for all groups (DabiriNejad 2004, 
96). This mission is conducted through cultural interaction such as beliefs, attitudes, preferences and other personality aspects of individuals that have been considered as the most important factors for controlling human behaviors in behavioral science-related theories. In this regard, a public favorablespace with the capability of gathering people together canleadto the development ofcultural interaction (Yazdanfar et al, 2013, 7). Collective life is alsoan opportunityforyouthtoget away from thestressesof everyday life and spend their leisure timeand have cultural interaction and is an opportunity for people of different groups to gather together and enjoy freedom of speech and express their ideas, thusincreasingtoleranceof different groups which is encouraged among them can create more socializationand anactiveandlively space (Behzadfar and Tahmasebi, 2013, 19). Regarding the importance of interaction between people and the fact that it has not been considered seriously in today's design in the country, The present studyis toinvestigatethe factors influencingthe design ofpublicplacessuch as thecontemporary art museumto providestrategies forincreasingculturalinteractionin the community.

\section{Statement of the problem}

The study of evolution, in the midst ofallhuman phenomenais the most charismatic, and perhapsthe historyof cultureand civilization can be counted as themost fascinating branch of history. Because culture and civilizationis as expended as human life, all from scientists to readers are eager to delve into the history and the past of their job and thought especially the history of the time by which they can observe and evaluate achievements. Culture is comprised of art, literature, the science of creation, philosophy and religion. Public culture is defined as ethnic solidarity, Coexistence, assistance, cooperation, friendship, love, andfinally, afactor of mutual understanding. Mutual understanding is a two-sided understanding which is a point where culture and art converge (architecture and culture, 1999).In other words, culture is a set of human valuable and spiritual dynamic achievements that are learnt over time and in different places (In the form of non-hereditary) and are transferred from one generation to another and therefore lead to excellence of mind and body and eventually to truth and human perfection. Thus, cultural globalization requires various cultural components and indicators to be considered. Culture in this sense, includes all valuable lessons and creativity of individuals and communities and includes all ideas and great, dynamic traditions, technical talks, cultural and artistic works and various methods of communication (Rezaienabard, 2012). In fact, themuseumwithrareandancientobjects, guardourcultural and artistic heritage. However, today function of museumshas changed considerably. Themuseumshould not be considered as a placewhereonlytheancient and historical monumentsare displayed. Allobjects being 
displayedin museums have messages to send to their visitors and we canperceivethese messages by contemplation. Oneof the most importantfunctions ofa museum is thecommunication it makes betweenvisitors andobjects displayed. In fact, we must striveto transfertheconnection and the feeling existed between thecreatorof a workandthe work itselftothevisitors, and thisis notbeyond reach because a work can make connections between the present and past time and thus people can observe their deep connection with ancestors who created our culture and recover their identity. By seeing historical objects in museums, people can observe the evolution of human thought in creation and innovation of works overtly and then can see the effects of last generation culture. It is because of the fact that human made objects are a reflection of every society culture and need. Therefore we could say that in today's world, museums as a cultural institution are passages where a generation's works are preserved for the next generation, various cultures are reflected, traditions and customs are crystallized, and cultural heritage of different nations from old times to the present time are shown and visitors' passing from this passage can build their recognition. Due to the fact that Iran is rich in art and culture; moreover, this artistic and cultural originality could be evident, thus by organizing it through various ways such as establishing contemporary art museum we can achieveglory, pride and identityincontemporaryart in today's youngsociety. The aim ofthisstudy with a cultural interaction approach is to identifyappropriate waysfor designingcontemporary art museums;moreover, in this studywe aretoanswer the following questions:

- Is the designandconstruction of a contemporary art museumwith the cultural interaction approach necessary in Sari - provincial capital city of Mazandaran, Iran?

- To what extent the citizens' personal characteristics (age, sex, education, etc.) can influence the design of a contemporary artmuseumwiththe cultural interaction approach?

- To what extent aresocial and culturalfeatures effectivein the design ofacontemporary artmuseumwith cultural interaction approach?

- Are the regional climatic conditionseffective in the design of contemporary artmuseumwith thecultural interaction approach?

- Is the quality ofthe designedspace effective inthe prosperity of contemporary artmuseumwiththe cultural interaction approach?

\section{Literature review}


Table 1: A summary of conducted studies in the field of assessment of strategies for improving design of contemporary art museum

\begin{tabular}{|c|c|c|c|}
\hline & researcher & Subject & Results \\
\hline 1 & $\begin{array}{c}\text { Behzad } \\
\text { DefroTahma } \\
\text { sebi(2013) }\end{array}$ & $\begin{array}{l}\text { Identification } \\
\text { and assessment } \\
\text { of the factors } \\
\text { affecting social } \\
\text { interactions }\end{array}$ & $\begin{array}{l}\text { The success of urban spaces is dependent on the use of that space } \\
\text { and human presence in it. In fact, the architecture must increase } \\
\text { social interactions and human solidarity and not encouraging } \\
\text { differentiation and separation. However, what we are facing } \\
\text { today in most urban areas is a decline in social participation of } \\
\text { residents in such spaces }\end{array}$ \\
\hline 2 & $\begin{array}{c}\text { Jamali and } \\
\text { Jamali } \\
\text { (2013) }\end{array}$ & $\begin{array}{l}\text { An analysis } \\
\text { oftheglobal } \\
\text { citiesand their } \\
\text { relationship } \\
\text { withurban } \\
\text { culture }\end{array}$ & $\begin{array}{l}\text { In their articles, they refer to the importance of globalization } \\
\text { and its effect on cities. Even the use of urban services can be a } \\
\text { subject for optimal designing and directing these cultures in a } \\
\text { better way. Thus, any decisions to encounter different cultures } \\
\text { can help the formation of a specific operation both socially and } \\
\text { physically. }\end{array}$ \\
\hline 3 & $\begin{array}{c}\text { Shoaryan } \\
\text { and Kazemi } \\
\text { (2012) }\end{array}$ & $\begin{array}{l}\text { Strategies to } \\
\text { achievesustaina } \\
\text { ble } \\
\text { architectureinc } \\
\text { ontemporaryart } \\
\text { museums }\end{array}$ & $\begin{array}{l}\text { In their article, these researchers showed that attention to } \\
\text { sustainable development, sustainable patterns ofarchitecture, } \\
\text { using naturalenergy, } \\
\text { fuelandcoexistencewithnatural conditions are essentialfor } \\
\text { avoiding pollution growth ofthe environment }\end{array}$ \\
\hline 4 & $\begin{array}{c}\text { AvazZadeh } \\
\text { and } \\
\text { QolamaliZad } \\
\text { eh (2012) }\end{array}$ & $\begin{array}{l}\text { Globalizationan } \\
\text { dpreservation } \\
\text { of cultural } \\
\text { valuesandindig } \\
\text { enousurban } \\
\text { textures }\end{array}$ & $\begin{array}{l}\text { In their article, these researchers showed that adherence } \\
\text { touniversal models, regardless ofcultural andindigenous values } \\
\text { can makethe urban view alien for residents. Thus, In order } \\
\text { tokeep thecultural valuesandlraniantraditional beliefs alive, it is } \\
\text { essential to determine and selectanappropriaterelationship that } \\
\text { is proportional tothe phenomenon of globalization rather than } \\
\text { acceptingthe domination of foreigncultures. }\end{array}$ \\
\hline 5 & $\begin{array}{l}\text { PurAhmad } \\
\text { et al (2012) }\end{array}$ & $\begin{array}{l}\text { Investigation } \\
\text { and analysis } \\
\text { ofthe role } \\
\text { ofmuseumsin } \\
\text { the } \\
\text { development } \\
\text { ofcultural } \\
\text { tourism }\end{array}$ & $\begin{array}{l}\text { In their article, with this assumption that Museum as an } \\
\text { attraction can add to tourism development especially cultural } \\
\text { tourism in destination, these researchers tried to investigate the } \\
\text { effect of museum attraction on cultural tourism status in the } \\
\text { east of Mazandaran. }\end{array}$ \\
\hline
\end{tabular}




\begin{tabular}{|c|c|c|c|}
\hline 6 & $\begin{array}{l}\text { SaberiNajafa } \\
\text { badi (2011) }\end{array}$ & $\begin{array}{l}\text { Teaching } \\
\text { philosophy to } \\
\text { children in } \\
\text { interactive } \\
\text { museums of } \\
\text { science }\end{array}$ & $\begin{array}{l}\text { Besides studying the proportion anditsrelationshipwith } \\
\text { theprogram ofteaching philosophy, also objectives and } \\
\text { valuescontained init, this articleintroduces theinteractive } \\
\text { museums, where visitors are supposed to be learners who can } \\
\text { contribute tobuildtheir knowledgesystems through their } \\
\text { interaction withobjects displayedin themuseums.Form } \\
\text { researcher's point of view, in todaychangingworld, learners } \\
\text { themselvesareinterested in exploration and recreation. }\end{array}$ \\
\hline 7 & $\begin{array}{l}\text { Ashrafi } \\
\text { (2010) }\end{array}$ & $\begin{array}{l}\text { Comparison } \\
\text { ofthe concept } \\
\text { ofecomuseum } \\
\text { withtraditional } \\
\text { museum }\end{array}$ & $\begin{array}{l}\text { Different perspectivesin the field ofmuseums,compare } \\
\text { indicators anddistinguishingactivitiesof eco-museumswith } \\
\text { traditionalmuseumsanddiscuss challengesfrom different aspects } \\
\text { such asstructure andformation anddifferent patterns } \\
\text { ofperformance. Surveyresultsshowedthat if thesemuseumsare } \\
\text { affected by majortouristobjectives, In long term, it can lead to } \\
\text { consumptionof theheritage in question and thenthey are } \\
\text { disvalued }\end{array}$ \\
\hline
\end{tabular}

\section{Theoretical foundations}

\section{Museum definition}

The wordmuseumin Persian is the pronunciation of the French word"Mouse" which has a Greekroot"Mouse" and is the name of all nineGreekgoddess ofart, poetryandmusic inAncientGreece. In English, Italian, etc.the word museumhas been used to mean "gazing, contemplating, and thinking" (Falahi, Ali 1966). Residents ofthe West defines this term as a placewhere theancient worksare kept and is considered to be a source of precious and delicate objects.... It can be said thatmuseum isthe scale of wisdom, degree of perception and reflection of orders. There, unsolvable problems are solved and historical knowledge of visitors is increased (Shirazi, 1992, 2)

The rootof thisword is taken from Greek word "Mousine" meaningthe domicile ofMouse,the Goddess of art and imageryinancient Greek mythology. This Greek term is pronounced "Museum" in English and "Mousee" in French. Around 1873,the word "Mousee" entered Persian from French. International Council of MuseumsICOMsays "The museumisapermanentandnonfinancial institutionwhose doors areopen to everyoneandserve thecommunity. The aim ofestablishing museums is to provide conditionsfor conducting researchon evidence and works inherited fromhuman generations and environments, and to collect, conserve, produce, and create a relationship between these works and specifically, 
display them in order to exploit them spiritually (Rahimi and Hosseini, 2009, 79). TO put it simply, themuseumcan be definedas a permanentnon-profitorganizationthatserves thecommunity and isopen to the public. This organizationcollects and protects and displays materialevidencerelatedtohumansand their environmentso that it can bestudied andtaught, and can be a source of enjoyment (Zahedi et al. 2008, 13).

\section{Classification of Museums}

Museums can be classified the best way by the collections they hold. Collection or the way museums' objects are considered is the basis of this collection. It is because of the fact the nature of theworksandideas is associated with itand determine thegoals and activities ofthe museum. Thus, in general, museums can be placed in three groups:

a) History(museum ofarcheology, anthropology)

b) Artistic ( museum of contemporary art)

c) Scientific (Museum ofgeology, botany, natural science and science and technology) (Nafisi, 2001, 34)

In modern world of today, the concept of objects and the way their values are displayed and transferredtovisitors have changed.Museumsarecommunicative tools of objects, andthey are ineffective unless they are in connection with humans.

Transfer of interest, information and values are the basis of educationandmuseums enjoy a special place incultural, educational, and researchpracticesincommunity level (Yavari, 1999, $66)$.

\section{Cultural interaction in a public space (The museum of contemporary art)}

Culturalinteraction is a relationship betweentwo or more peoplewhich leads toa reactionbetweenthemandthistype ofreactionis knowntoboth sides. "Actually,there are otherdefinitionsfor example, cultural and socialinteractionand communication, can be aphysicalissue, a look, a conversationor communication between people, which requiresthe definition ofappropriateevents and activitiesandthe roleofpeoplein a spaceandtheir participation inculturalgroupsandsocialnetworks. " (Daneshpur and Charkian, 2007, 22). What weare witnessingin today's society is a reduction in people's communicationwitheach other, although these spaces are considerably effective in the formation of meetings, chats and doing sociocultural activities (Yazdani and Teymuri, 2013, 84).

Today, One of the approaches that has been considered for reviving the society, is attention to its public spaces, and it is believed to have significant impact on determination of the identity of the city and eventually, promotion of citizens' culture (Rafeyan, 2013, 16), because these places are convenient for people. Hence, they can be places forlocalcitizens to 
visit constantly.Differentspacesin apublic placesuch as(museum of contemporary art with the cultural interactions approach) make it possible for people tovisit different generations (Behzadfar and Tahmasebi, 2013, 18).

\section{Objective}

- Recognizing the necessity of designing and constructing contemporary art museum with the cultural interaction approachin Sari- provincial capital city of Mazandaran.

- Recognizing the effect of residents' personal characteristics on the necessity of designing.

- Identifying Mazandaran climate and climatic factors affecting constant architecture and presenting the bases of designing museums.

- Identifying the effect of qualitative indicators (light, green space,semi-open spaces etc.) on design desirability.

- Recognizing residents' cultural and social conditions in the necessity of design.

\section{Research methodology}

According to the nature, subject and objective predicted for this research, we could say it is a descriptive-analytical research and can be categorized as applied research studies. Since questionnaire and interview were used for collecting required data, this research can be survey research. Required data were collected through both libraries and surveys. Statistical population in this research is all citizens living in Sari- provincial capital city of Mazandaran. Systematic random sampling was conducted according to Morgan table and questions were given to 384 respondents. After collecting survey data through completed questionnaires, and by using SPSS software, Kolmogorov-Smirnovtest and binominal test, variables and their relationships were studied.

\section{Hypothesis and discussion}

Results are the most important part of research that lead to the development of hypotheses and add new information to past knowledge with the help of research theories (Hafeznia, 2003). 
Table : Qualitative characteristics of the research samples

\begin{tabular}{|c|c|c|c|c|c|c|c|}
\hline \multicolumn{2}{|c|}{ variable } & \multirow{2}{*}{$\begin{array}{r}\text { frequency } \\
212\end{array}$} & \multirow{2}{*}{$\begin{array}{r}\text { percentage } \\
55.7\end{array}$} & \multicolumn{2}{|c|}{ variable } & \multirow{2}{*}{$\begin{array}{l}\text { frequency } \\
49\end{array}$} & \multirow{2}{*}{$\begin{array}{l}\text { perce } \\
\text { ntage } \\
13.3\end{array}$} \\
\hline \multirow[t]{2}{*}{ sex } & female & & & \multirow{7}{*}{ 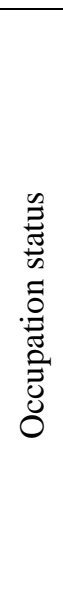 } & governmental & & \\
\hline & male & 168 & 44.3 & & Self-employed & 113 & 30.5 \\
\hline \multirow{6}{*}{ 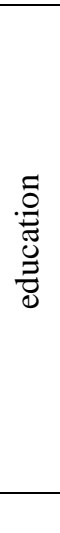 } & $\begin{array}{l}\text { Under } \\
\text { diploma }\end{array}$ & 56 & 14.89 & & retired & 31 & 8.25 \\
\hline & diploma & 36 & 9.47 & & University student & 39 & 10.37 \\
\hline & $\begin{array}{l}\text { associate } \\
\text { degree }\end{array}$ & 48 & 12.77 & & housewife & 78 & 20.74 \\
\hline & $\begin{array}{l}\text { Bachelor's } \\
\text { degree }\end{array}$ & 135 & 46.64 & & jobless & 20 & 5.32 \\
\hline & Master's degree & 49 & 13.03 & & student & 46 & 12.24 \\
\hline & $\mathrm{PhD}$ & 12 & & & total & 380 & 100 \\
\hline
\end{tabular}

Source: the author (2015)

\section{The normality of data distribution (Kolmogorov-Smirnovtest)}

Most statistical tests including parametric tests are based upon the normality of data distribution and they are applied with this presumption that data distribution in a community or in samples selected from the community follows a normal distribution. Thus, before conducting any statistical analyses on variables, analyzers need to know variables type of distribution. Applying Kolmogorov-Smirnov test, we can achieve this objective. In Kolmogorov-Smirnov test, null hypothesis is that data follow a normal distribution; on the other hand, the alternative hypothesis is that data don't follow a normal distribution. According to the table presented below, as it can be seen in this test, the probability level and $\mathrm{P}$ value is more than error level in all variables (0.05). Given the $\mathrm{P}$ value, Null hypothesis is not rejected and so data distribution is considered to follow a normal distribution. Consequently, parametric tests have been used for testing research hypotheses.

Table 3: Kolmogorov-Smirnov test results for evaluating the normal data distribution

\begin{tabular}{|c|c|c|c|c|c|}
\hline variable & $\begin{array}{c}\text { Statistical } \\
\text { indicator }\end{array}$ & number & $\mathrm{Z}$ & $\begin{array}{c}\text { Significance } \\
\text { level }\end{array}$ & \begin{tabular}{c} 
Test result \\
\hline $\begin{array}{c}\text { Factors affecting promotion } \\
\text { of museum design quality }\end{array}$
\end{tabular} \\
\hline
\end{tabular}


According to the statistical value in Kolmogorov-Smirnov test for variables, significance level was $\mathrm{P}>0.05$. Thus it can be concluded that above variables enjoy normal distribution and so we can apply Pearson test.

\section{Evaluation of the research main hypothesis}

H0: Seemingly, in comparison with personal and social factors ( personal features such as religious beliefs, culture etc.) qualitative factors (the quality of spaces designed for museums) are more effective for contemporary art museum to be welcomed.

H1: In comparison with personal and social factors (personal features such as religious beliefs, culture etc.) qualitative factors (the quality of spaces designed for museums) don't seem to be more effective for contemporary art museum to be welcomed.

Table 4 -"Results of Binominal test for the comparison of frequency of responses less than average with responses in average and above average, regarding the effect of qualitative factors compared to social factors"

\section{Binomial Test}

\begin{tabular}{|ll|r|r|r|r|r|}
\hline & & $\begin{array}{r}\text { Categ } \\
\text { ory }\end{array}$ & $\mathrm{N}$ & $\begin{array}{r}\text { Observed } \\
\text { Prop. }\end{array}$ & Test Prop. & $\begin{array}{r}\text { Exact Sig. (2- } \\
\text { tailed) }\end{array}$ \\
\hline Hypotheses & Group $\mathrm{H}$ & KHEIR & 183 & .48 & .50 & .826 \\
& 1 & & & & \\
& Group 2 & OBALE & 197 & .52 & & \\
& Total & & 380 & 1.00 & & \\
\hline
\end{tabular}

Source: the author (2015)

Results of table 2 show that the frequency of responses more than average was 384(52\%) and the frequency of responses less than average was $48 \%$. Given the fact that $\mathrm{P}$ value is less than 0.05 , the distribution difference in 2 groups turned out to be significant at $99 \%$. Therefore, H0 that stated in comparison with personal and social factors ( personal features such as religious beliefs, culture etc.) qualitative factors (the quality of spaces designed for museums) are more effective for contemporary art museum to be welcomed, is accepted.

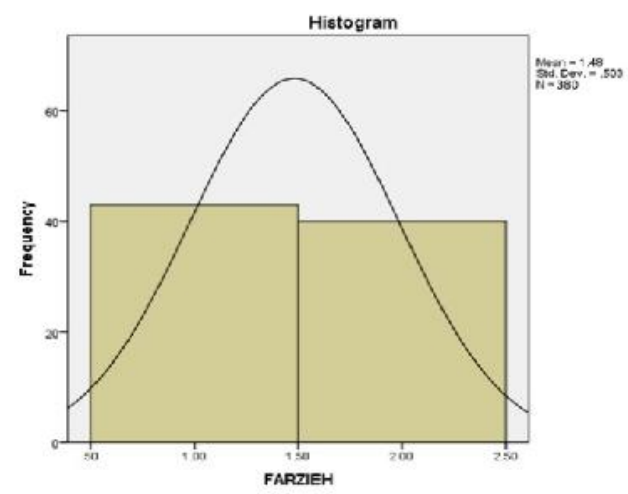

Fig 1: Responses items - source: the author (2015) 


\section{Frequency distribution of samples' responses number and percentage}

In the survey, citizens were asked questions about factors affecting the promotion of contemporary art museum design. It should be noted that qualitative and social factors were tested separately. The survey results indicateuser's sociocultural conditions, economical status of visitors, the sense of peace felt by people due to their attendance are the most effective factors in the category of social factors and aesthetic style designed for the set, easy access to the collections and availability of educational facilities are the most effective factors in the category of qualitative factors. Tables 5 and 6 provide the percentage frequency of responses.

Table 5: Scoring social factors affecting people to welcome contemporary art museum

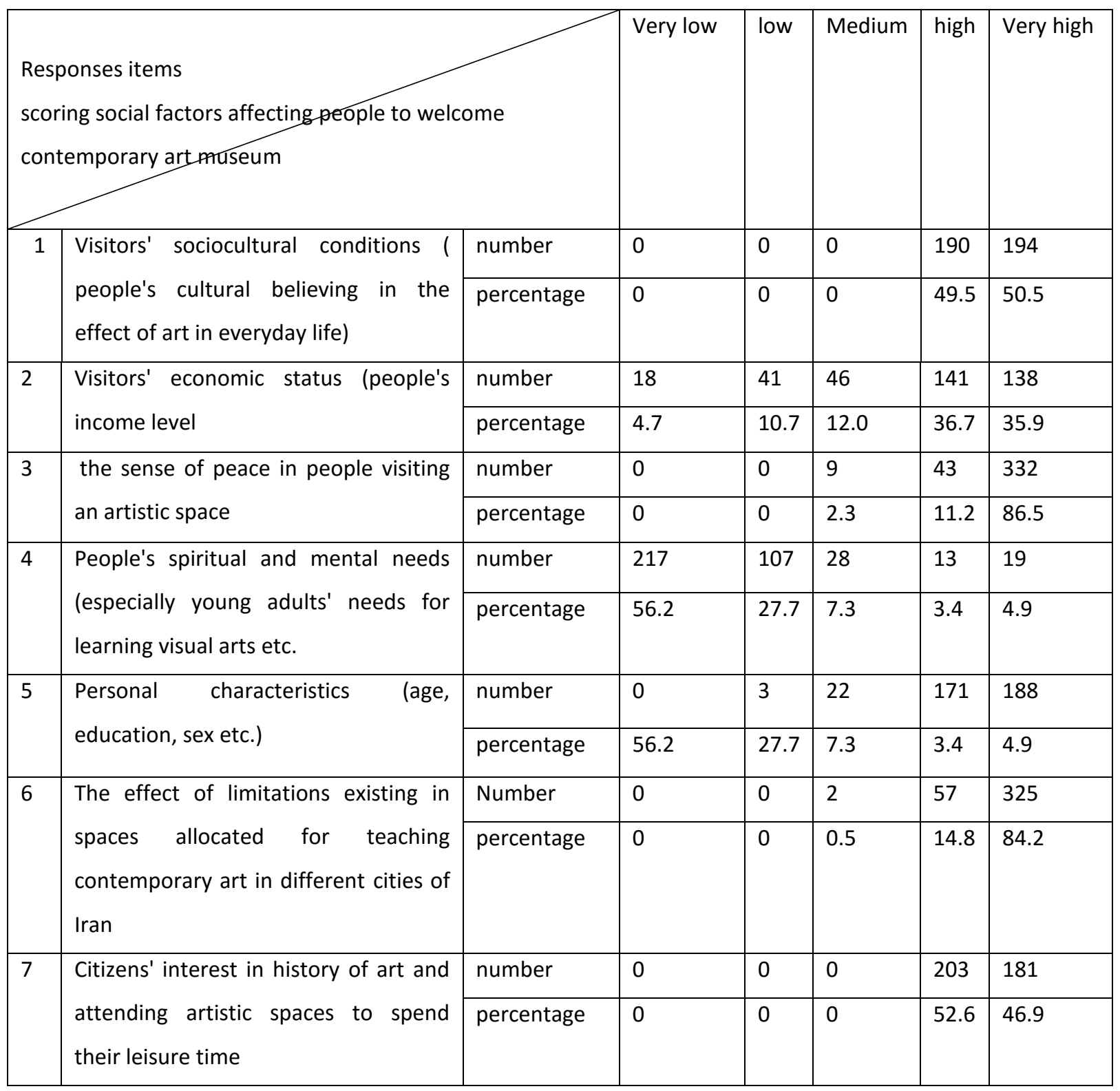


Table 6: Scoring qualitative factors affecting people to welcome contemporary art museum

\begin{tabular}{|c|c|c|c|c|c|c|c|}
\hline \multicolumn{3}{|c|}{$\begin{array}{l}\text { Responses items } \\
\text { scoring qualitative factors affecting peopte to welcome contemporary art } \\
\text { museum }\end{array}$} & $\begin{array}{l}\text { Ve } \\
\text { ry } \\
\text { lo } \\
\text { w }\end{array}$ & lo & $\begin{array}{l}\text { Mediu } \\
\mathrm{m}\end{array}$ & high & $\begin{array}{l}\text { Ve } \\
\text { ry } \\
\text { hig } \\
\text { h }\end{array}$ \\
\hline \multirow[t]{2}{*}{1} & \multirow[t]{2}{*}{$\begin{array}{l}\text { Aesthetic style (integration of architecture and visual art in } \\
\text { shape and style of museum }\end{array}$} & number & 0 & 0 & 0 & 190 & $\begin{array}{l}19 \\
4\end{array}$ \\
\hline & & $\begin{array}{l}\text { percent } \\
\text { age }\end{array}$ & 0 & 0 & 0 & 49.5 & $\begin{array}{l}50 . \\
5\end{array}$ \\
\hline \multirow[t]{2}{*}{2} & \multirow{2}{*}{$\begin{array}{l}\text { The existence of educational facilities in museums needed } \\
\text { for holding visual arts competitions and public visiting of } \\
\text { artists' works }\end{array}$} & number & 18 & 41 & 46 & 141 & $\begin{array}{l}13 \\
8\end{array}$ \\
\hline & & $\begin{array}{l}\text { percent } \\
\text { age }\end{array}$ & 4.7 & $\begin{array}{l}10 . \\
7\end{array}$ & 12.0 & 36.7 & $\begin{array}{l}35 . \\
9\end{array}$ \\
\hline \multirow[t]{2}{*}{3} & \multirow{2}{*}{$\begin{array}{l}\text { The existence of visual attractions and desirable views such } \\
\text { as green spaces, } \\
\text { fountainsandarchitecturalelementsformakinginteractionand } \\
\text { dialogueandplaying music in the space }\end{array}$} & number & 0 & 0 & 9 & 43 & $\begin{array}{l}33 \\
2\end{array}$ \\
\hline & & $\begin{array}{l}\text { percent } \\
\text { age }\end{array}$ & 0 & 0 & 2.3 & 11.2 & $\begin{array}{l}86 . \\
5\end{array}$ \\
\hline \multirow[t]{2}{*}{4} & \multirow[t]{2}{*}{$\begin{array}{l}\text { Making the space dynamic and attractive by providing } \\
\text { adequate lighting both inside and outside the building }\end{array}$} & number & $\begin{array}{l}21 \\
7\end{array}$ & $\begin{array}{l}10 \\
7\end{array}$ & 28 & 13 & 19 \\
\hline & & $\begin{array}{l}\text { percent } \\
\text { age }\end{array}$ & $\begin{array}{l}56 . \\
2\end{array}$ & $\begin{array}{l}27 . \\
7\end{array}$ & 7.3 & 3.4 & 4.9 \\
\hline \multirow[t]{2}{*}{5} & \multirow{2}{*}{$\begin{array}{l}\text { The effect of colors used in design of museum building } \\
\text { (inside and outside the building such as happy and exciting } \\
\text { colors) }\end{array}$} & number & 0 & 3 & 22 & 171 & $\begin{array}{l}18 \\
8\end{array}$ \\
\hline & & $\begin{array}{l}\text { percent } \\
\text { age }\end{array}$ & 0 & 8.0 & 5.7 & $\begin{array}{l}44.3 . \\
7\end{array}$ & $\begin{array}{l}48 . \\
7\end{array}$ \\
\hline \multirow[t]{2}{*}{6} & \multirow{2}{*}{$\begin{array}{l}\text { the existence of an appropriate place for inviting great } \\
\text { artists ofcontemporary art and promoting the activities (by } \\
\text { holding lectures and teaching modern methods in visual } \\
\text { arts }\end{array}$} & Number & 0 & 0 & 2 & 57 & $\begin{array}{l}32 \\
5\end{array}$ \\
\hline & & $\begin{array}{l}\text { percent } \\
\text { age }\end{array}$ & 0 & 0 & 0.5 & 14.8 & $\begin{array}{l}84 . \\
2\end{array}$ \\
\hline \multirow[t]{2}{*}{7} & \multirow[t]{2}{*}{$\begin{array}{l}\text { The effect of colors used in external and internal design of } \\
\text { the museum (e.g. using happy and exciting colors). }\end{array}$} & number & 0 & 0 & 0 & 203 & $\begin{array}{l}18 \\
1\end{array}$ \\
\hline & & $\begin{array}{l}\text { percent } \\
\text { age }\end{array}$ & 0 & 0 & 0 & 52.6 & $\begin{array}{l}46 . \\
9\end{array}$ \\
\hline \multirow[t]{2}{*}{8} & \multirow[t]{2}{*}{$\begin{array}{l}\text { The effect ofcommercial spaces in the set (sales of visual } \\
\text { art- related objectssuch asposters, } C D \text {, etc.) }\end{array}$} & number & 0 & 0 & 0 & 185 & $\begin{array}{l}19 \\
9\end{array}$ \\
\hline & & percent & 0 & 0 & 0 & 47.9 & 51. \\
\hline
\end{tabular}




\begin{tabular}{|c|c|c|c|c|c|c|c|}
\hline & & age & & & & & 6 \\
\hline \multirow[t]{2}{*}{9} & \multirow{2}{*}{$\begin{array}{l}\text { Appropriatefacilities making the space more } \\
\text { comfortableandenjoyableindifferentclimatic } \\
\text { conditions(rain, humid, wind, etc.) }\end{array}$} & Number & 0 & 4 & 17 & 37 & $\begin{array}{l}32 \\
6\end{array}$ \\
\hline & & $\begin{array}{l}\text { percent } \\
\text { age }\end{array}$ & 0 & 1.0 & 4.4 & 9.6 & $\begin{array}{l}84 . \\
5\end{array}$ \\
\hline
\end{tabular}

Source: the author (2015)

\section{RESULTS AND RECOMMENDATIONS}

Today with technological advances and the change has occurred in people's life, interests have changed a lot in the society. The study conducted on the extent to which people in Tehran welcomed the museum of contemporary art shows that this construction and all works displayed there are highly welcomed by the public. This type of museum not only encourages people to visit them but also provide a place for interaction between culture and art in Iran and in international level. With thedevelopment of societiesinrecent decades, theneed forthese spacesin citiesother than the capital city has become more importantthan ever. In this case, bystudying effective factors, theresponsesmade by sampleswere examined. The results indicated that although thesocial and individual factorssuch as age, religionandeconomicstatus of thefamiliescan affect people's attendance at such places, using appropriate strategiesindesigning it is possibleto encourage all groups of the society to visit these spaces. According to the analytical findings and recommendation made by Sari residents, the following are suggested:

\section{Attention to exquisite design that is commensurate with the museum applicability:}

The results fromquestionnairesshow thatappearance plays an important role and can attract more visitors. Due to existing needs in Sari as the provincial capitalof Mazandaran, exquisite design and the use of structural systems can attract more people, even from other cities.

\section{The availability ofspaceand familiarity with that:}

Accordingtothedailytrafficin the cityandmoreuseofprivate vehicles, theavailabilityandlocationofthebuildingin an areawithfacilitiesforparkingandspacesecurity, and not imposing more traffic tothe cityare amongthe most importantfactorsin designing. The resultsachieved from the samplesemphasize thisissue.

\section{Designing a space that induces a sense of relaxation to visitors:}

Creating a sense ofrelaxationandalleviatingeveryday stressand tensionin peopleare among the most important factors thatshouldbe considered. Usingspeciallighting, selecting the 
correcttonesin interior designandexteriorbody of the buildingas well as designing greenspaces accordingtothemethodsof environmental psychology can help achieve this factor.

\section{Considering an appropriate place for inviting adept instructors:}

Cities in Iran are suffering from the paucity of cultural and social facilities. The lack of an appropriate place for inviting well-known instructors and taking advantage of their experience has always been artists' concern in this city. By designing such places (contemporary art museum) not only it is possible to remove this need but also we can change this exhibition to an applicable space.

\section{REFERENCE:}

- Avazzadeh, Shadi, Gholamalizadeh, H.(2012), "Globalization andthe preservation ofcultural and indigenous valuesofurbantexture", the firstnational conference of ideasandnew technologiesin architecture, TabrizarchitectsForum.

- Ashrfy, M, "Comparative Study of the concept ofeco-museum withtraditionalmuseum", thequarterly journals ofthe Art, 2010, 4:13-25.

- Bhzadfr, Mustafa, Tahmasebi, A, "Identificationand evaluation offactors affectingsocial interactions," Journal of Baq-e- Nazar, summer, 2013, 10(25), 17-28.

- Dabirinejad, R, (2004), "museums: yesterday, today, tomorrow", $1^{\text {st }}$ issue, Sahat publication, p. 96.

-Daneshpur, SyedAbdul HadiandCharkhchian, Maryam., "public spaces andfactors affectingcollective life", Journal ofBaq-e-Nazar, 2007, 7: 19-28.

- Dasam, D., "descriptive guide on establishing museums witha look at theEcoMuseum", thetranslation ofMoradi,Z, Salehi,A, $1^{\text {st }}$ issue, Tehran: Samira publication, 2008: 70-120.

- Falahi, A, "Historyof Museum", 1966, 1: 20-60.

- Hafeznia,2009, An introduction to methodology of Humanities, $16^{\text {th }}$ publish, Tehran, SAMT publication

- Jamali, Elaheh, Jamali, Nushin, (2013), "An Analysis of theglobal citiesand its relationship withurban culture", the firstnational conference onurban planningandarchitectureover time, QazvinUniversity.

- Kasiri,Masood, "the need for the establishment of theIsfahan Museumof MedicalHistory," Iranian Journal ofMedicalEthics and History, 2012, 5: 70-72.

- Lotfi, S, "An analysis of Museum"virtual, Ertebat monthly, 2007, 7: 74-82.

- Mirzaee, Karam, Nadalian, A., "The Case study of six modern works inTehranMuseum of Contemporary Art", Journal of Yeksareh, 2009, 13: 93. 
-Nafisi, Nushindokht, "museum holding", SAMT publications, Iranian Cultural Heritage Organization, 2001: 34-42.

-Purahmad, M., Mahdian Bahnamiri, MirzaieKotnaie, Mohammadi, "Investigation and analysis of the role ofmuseumsin the development ofcultural tourism", Journal ofTourismPlanning and Development, First Year, 2012,1: 105-128.

- Rafieian, Mojtaba; Azimi, Maryam; Moqadam, H. "Assessment of the quality of urban areasin the enjoymentofurban public spaces",Amayesh journal, 2012, 16: 33-49.

- Rahimi, E.,Hosseini, R., "The Journal of Art and architecture", 2009, 12: 79-83.

- Rezainabard, Amir, "Theeffects of globalizationoncontemporary art inthe West(from 1960tillnow)", Journal ofStrategic Studies onGlobalization, 2012, 3(6).

- SaberiNajaf Abadi, M., "teaching philosophy to children ininteractive museumof science", Journal ofthinkingandChildren, Institute for Humanitiesand Cultural Studies, second year, 2011, 1: 51 .

- SharyanStari, Vida, Kazemi, Mehrvash, "Thestrategies to achievesustainable architectureincontemporary art museums", Tehran University,Faculty of Environment.

- Shyrazy, B., (1992), "The image of national museums", Journal ofmuseums, Iraniancultural heritage organization, 2012, 12: 2.

- Yavari, A. ", from museum to museum", Journal of museums, 2008, 88: 66.

- Yazdan Far, SayyedAbbas; Hosseini, SeyedBagher; Zarvady, M. "public spaces andincreasingsocial interactions", The journal of Urban Management, 2013, 32: 7-22.

- Zahedi, Muhammad. Hajiha, Bahareh, KaiambashiI, M.(2008), "the museum, museum holding and museums", second edition, Isfahan: Chaharbaq publication.

\section{How to cite this article:}

Galogahi S Z, Beheshti H M, Alishah M, Rasooli S R. Appropriate strategies for designing contemporary art museums with the aim of attracting more people in sociocultural spaces of the country ( case study: sari, mazandaran). J. Fundam. Appl. Sci., 2016, 8(2S), 1466-1480. 